\title{
Rewriting the Origin of New Media: History and Postcoloniality in Nam June Paik's Video Art
}

\author{
Koonyong Kim
}

\begin{abstract}
This essay draws together new media studies and postcolonial/ethnic studies, two academic disciplines often thought to have little in common, in order to cast new light on the work of Korean-born video artist Nam June Paik. Paik has been considered the "founding father of video art" and is often said to have expanded the concept of contemporary art and new media aesthetics. However, his video art has often been regarded as an ahistorical postmodern art form in contemporary theoretical discourse. This brief and preliminary intervention challenges that widely-held view and offers a new historical understanding of postmodern new media by excavating his relatively unknown career as a postcolonial composer. By paying close attention to Paik's musical work and his critical engagement with Western composers such as Schoenberg, I demonstrate how his deconstruction of modern and postmodern music in the West paved the way for his own invention of postmodern video as a "postmusical" narrative. I also consider Paik's postcolonial rewriting of Korean history, as well as his thematization of a contemporary global economy that is underpinned and facilitated by transnational networks of information, communication, and cultural formations. In doing so, I contextualize the genealogy of Paik's oeuvre within the complex constellation of modernity, coloniality, postmodernity, and postcoloniality, and thereby unpack the multilayered and palimpsestichistoricity of postmodern visual art.
\end{abstract}

Index Terms-Nam June Paik, new media, postcolonial, postmodernism.

\section{InTROdUCtion: NAM JUNE PAIK, A POSTCOLONIAL COMPOSER}

Often called the "founding father of video art," Nam June Paik (1932-2006) is often said to have heralded and prefigured the ascendance of contemporary new media culture. The pioneering role he played in the inception and evolution of video art and new media is such that Edith Decker-Phillips asserts, "For a profile of the development of video art today, we need look no further than to the work of Nam June Paik, as no one has contributed more to it than he" [1]. Nonetheless, many critics have regarded Paik's work as a prototypical articulation of the postmodern impulse toward a "pure and random play of signifiers," claiming that his video art lacks any depth and cannot properly deal with history. Thus Paik's video narrative has too often been looked upon as asymptom of what Rosalind Krauss characterizes as "the leveling out of the effects of temporality" or an "aesthetics of narcissism" [2]. Noteworthy, however, is that in such sweeping accounts, Paik's sense of history as a postcolonial subject or his conflictual relationship with Western modernism or postmodernism is ignored altogether. One may

Manuscript received December 25, 2015; revised February 25, 2016.

The author is with the Department of English at the University of San Diego, CA, USA (e-mail: kykim@sandiego.edu). find this persistent inattention to Paik's postcolonial position baffling and highly problematic, given that history as such, or the question of rewriting history, is placed at the very center of postcolonial discourse and praxis.

As a way of bringing the question of history back into our discussion of Paik's video art in particular and postmodern new media culture more generally, my brief and preliminary intervention seeks to call attention to Paik's relatively unknown career as a postcolonial composer and to suggest some meaningful ways to historicize the ontology and genealogy of his oeuvre. Ultimately, this essaywill argue that if, as many commentators have pointed out, Paik's video art is indeed one of the most representative forms in postmodern multimedia culture, it is not because it is ahistorical, but precisely because the genealogy of his art form itself registers and problematizes the complexly intertwined histories of modernization, colonialism, postcoloniality, and postmodernism that have given rise to the present historical conjuncture. In line with such an argument, it will also be suggested that Paik's video art gives historical expression to the emergence of a new global world system that is coordinated and undergirded by rhizomatic and decentered transnational networks of economic, social, and cultural formations.

\section{Postmodern Video ART And Its Genealogy: Three SITES OF MODERN AND CONTEMPORARY HISTORY}

\section{A. "Postmusic": A Critique of Western Classical Music}

Although numerous eulogies and paeans have been bestowed on Paik's trailblazing artistic innovation, little attention has been given to his career as a composer. Insofar as our discussion turns on the historicity of Paik's video as a new cultural form, the disregard that many cultural critics have for his commitment to music is peculiar. For music is, first and foremost, a temporal genre; and as the work of Theodor W. Adorno, Edward W. Said, and Max Weber on music aptly illustrates, compositional practice oftentimes reflects the way in which a composer deals with temporal raw material and, by extension, the way in which a particular historical epoch conceives and imagines time and history [3]. That music played a key role in Paik's artistic peregrinations is unmistakable. As he explains in an interview, he "discovered" Schoenberg in 1947, at the age of fourteen, in the newly liberated" Korea. The German composer's twelve-tone technique considerably reshaped and transformed the Korean composer's "spiritual landscape" [4]. Thus when he attended the University of Tokyo after the Second World War as a postcolonial subject, he wrote his graduation thesis in 1956 onSchoenberg's twelve-tone music. During the early phase of Paik's career as a musician in 
postcolonial Korea and post-imperial Japan, it was his central concern to recast and reconfigure Korean music through Schoenberg's modern techniques. Such an abstract and depersonalized form of Western musical modernism [5] was not completely without strategic advantages, in that it allowed Paik to avoid copying Japan's traditional music and to rationalize and "modernize" Korea's musical conventions [6].

However, Paik's postcolonial project of revitalizing Korean music through Schoenberg's dodecaphonic music in the cultural landscape of postwar Japan was not entirely successful as it involved embracing Western culture in favor of the former colonizer's culture (in this case, Japanese culture). And yet Paik's "heavy minority complex," as he called it [7], as well as his admiration for Schoenberg, took a radical turn when Paik moved to Europe and held his first solo exhibition in 1963, entitled "Exposition of Music-Electronic Television." At the time, he reflectedas follows in his essay "New Ontology of Music": "I am tired of renewing the form of music — serial or aleatoric, graphic or five lines, instrumental or bellcanto, screaming or action, tape or live...I must renew the ontological form of music" [8]. Such an expressive and persistent will to deterritorializethe ontology of Western musical forms led him to conceptualize the notion of "postmusic."

Worthy of special attention here is that his search for "postmusic" incorporates into its new ontological form asignificantnon-musical medium - that is to say, television. In "Afterlude," an essay written after the exhibition, Paik makes clear that his televisions are an integral component of his postmusic [9]. Such a perspective sheds light on the idiosyncratic, if not quixotic, coupling of the two different media at the exhibition, suggestively named "Exposition of Music_Electronic Television." That is to say, the historical significance of Paik's first solo exhibition lies in the very fact that the two art media - music and television - are handled as one and the same medium in order to realize what Paik conceptualizes as "postmusic." Or, better still, it is of prime importance to point out that as music "draws a line of flight" from its conventional terrains and configurations, to use Gilles Deleuze's well-known phrase [10], one medium is constantly in the process of being translated into the other. In other words, if "postmusical" works such as Paik's famous Klavier Integral turn music into a visual spectacle, TV Room incorporates a visual medium into the realm of "postmusic."

It is this simultaneous mechanism of becoming-visual of the musical and becoming-musical of the visual, by virtue of which Paik's pursuit of a new ontology of "postmusic" ultimately leads to the "invention" a new art form: video art. Music is no longer confined to its customary parameters as he brings televisions into his all-inclusive medium of postmusic. Speaking of Beethoven, Schoenberg, and postwar Western avant-garde composers, Paik describes his postmusic as "a bastard the parents of which we do not know." By means of "bastardizing," or what Homi K. Bhabha terms "mimicry" [11], Paik seeks to challenge dominant modes of Western music, be it modern or postmodern music, all the while articulating his postcolonial vision of a new art form. It is none other than such a strenuous attempt to overcome Western modernity and postmodernity in music that needs to be taken into account when one unpacks the "historicity" of Paik's video art as an innovative contemporary art form.

\section{B. A Palimpsest of Postmodernity and Postcoloniality}

In conjunction with such a radical reconfiguration of Western music, it repays our attention that Paik's first exhibition sought to foreground and reaffirm Korea's history as an independent nation. Particularly remarkable is that he printed the exhibition poster on a Korean newspaper dated May 11th, 4293. 4293 is the year 1960 according to the traditional Korean calendar system, dangi, a system that originated from the mythical foundation of Korea in 2333 BC by King Dangun. As Paik thus ingeniously contextualizesand inscribes his independent artistic endeavors within Korea's long, autonomous history, the postcolonial composer challenges the imposition of a Western-centered historiography and brings to the foreground his proud in his national history. Given that a series of systematic attempts was made during Japan's colonial rule to distort and extirpate ancient Korean history, it is anything but surprising that King Dangun's symbolic meaning becomes the focal point of Paik's postcolonial project. Paik further uses Dangun as a symbolic figure in other works. For instance, in Dangun as a Scythian King, he celebrates one of the most glorious historical periods in Korean history, when the country's geographical territory and national imaginary expanded all the way into Manchuria. Since Manchuria was the center of Korean independence movements under Japanese colonialism, Paik's relinking Korea to the region is all the more significant. In doing so, Paik appropriates postmodern multimedia art as a way to celebrate and rewrite the magnificent historical past of his now impoverished, postcolonial nation.

\section{Paik's Satellite Video Art: Historicizing New Media and the Rise of a Global Network of Informatics and Communication}

In addition to Paik's deconstruction of Western music and his postcolonial rewriting of Korean history, it is also crucial to our historical and historicizing account of his multimedia work to note that his video art incessantly engages and thematizes a global network of information and communication in the contemporary world. His satellite video art, in particular, concretizes his dream of a global television that could connect the five oceans and six continents by way of new media technology. Wrap Around the World (1988), for instance, is a satellite link-up that connects a number of countries on the globe and features transcultural performances. In such a work, Paik exquisitely historicizes and envisions the full-fledged emergence of a transnational economy that is grounded in and mediated by cybernetics and digital technology. In a letter to John Cage, Paik explained that his satellite art might be regarded as a Wagnerian total work of art [12]. In spite of this allusion to Wagner's Gesamtkunstwerk, it cannot be overstressed that Paik's global art form does not uncritically mimic Wagner's musical modernism. Quite to the contrary; as he explains in his interview with O-ryong Lee, the concept of "wrapping around the world" is derived from the bojagi, a square-shaped traditional Korean wrapping cloth. While it contains various things, the bojagi does not impose any fixed order or form and also changes its own shape in accordance with what is contained inside. As an inclusive and flexible aesthetic form, therefore, the bojaginicelysuits Paik's endeavor to envisionthe "Global Village" and its transcultural communication through the lens of Korean traditional culture. 
Within the context of Paik's postcolonial spirit deeply embedded in his formal innovation, however, it does not seem impertinent to suggest that his vision of satellite video art is informed and reimagined by Korean shamanism. It is noteworthy that a Korean spiritualistic medium called mudang takes center stage in Paik's satellite art. Global Groove(1973) features a mudang or female shaman, and in Wrapping Around the World, Paik himself plays the role of a male shaman. As a shamanistic medium, the mudang mediates among people, between people and gods, and between the dead and the living, thus restoring a sense of wholeness or harmony in the universe. In addition, a mudang is a mystic, fortune-teller, doctor and pharmacist, priest, dancer, and singer, all rolled into one. Hence the idea of mudang as a versatile and all-around medium appears perfectlywell-suited to Paik's postcolonial mimicry that strives to reconfigure Wagner's comprehensive musical form through his own satellite video art. Furthermore, given that historically shamans were demonized by Western Christian missionaries and driven underground during Japanese colonial rule, Paik's foregrounding of the mudang in his multimedia work can be seen as another postcolonial endeavor to recuperate and galvanize Korean cultural traditions in transcoding Western art forms. In this sense it is quite plausible that Paik conceives of his satellite video art as a kind of Korean shamanistic ritual, in which he transfigures himself into a postcolonial medium who appropriates Western modern music and postmodern multimedia while performing his transformative ritual that connects different parts of the globe.

\section{CONClusion: Towards A New HeRmeneutics}

In view of Paik's critical appropriation of postmodern multimedia from the perspective of a postcolonial medium, as well as his "bastardization" of the West's modern and postmodern music, it is neither sufficient nor adequate to characterize his formal innovations as another prototypical expression of ahistorical postmodernism.Rather, if Paik's video art is "the art form par excellence of late capitalism" as Fredric Jameson astutely observes in his trailblazing magnum opus, Postmodernism, or, the Cultural Logic of Late Capitalism [13], it is in no way because his art form is oblivious to history. To the contrary, it is precisely because his artistic peregrinations register and lay bare the convoluted and even contradictory historical processes involved in the making of the present historical conjuncture. In other words, grounded in Paik's minority position within the cultural terrains of postimperial Japan and the modern and postmodern West, his innovative video art symptomatically inscribes the overdetermined and multilayered histories of colonialism, modernization, postmodernism, postcoloniality, and globalization into its palimpsestic form. With respect to Paik's originality as a visionary, American video artist Bill Viola remarks, "He really had a vision of the artist being part of the worldwide cultural network. It was totally before the web. The world we are living in right now is his world. He visualized that. He was the pioneer" [14]. Indeed, he was the pioneer: his multimedia narrative provides us with an intricate mapping of a global network society in which a host of related questions about modernity and coloniality and their lingering postwar legacies still remain inextricably interwoven and unresolved. His video narrative, in its form and content, visualizes such entangled histories of the contemporary world as well as his entanglement in those histories. Our reevaluation of Paik's work, therefore, should call vigilant attention to this historical complexity of his art form.As a way to do justice to Paik's palimpsestic work and to understand the complex histories of our contemporary globalizing world, we have yet to come up with a new hermeneutics that can account for the intertwining of his postmodern multimedia work and his postcolonial imagination.

\section{ACKNOWLEDGMENT}

The author would like to extend his most heartfelt thanks to Professor Fredric Jameson at Duke University for introducing himto the prismatic world of literature, critical theory, and many other cultural forms: "Là, tout n'estqu'ordre et beauté, Luxe, calme et volupté.” A special thanks also goes to Professors Susan Willis, Michael Hardt, Priscilla Wald, and Maurice Wallace, as well as to the Nam June Paik Studio in NYC and the Nam June Paik Art Center in South Korea.

\section{REFERENCES}

[1] E.Decker-Phillips, Paik Video. Trans. M.-G. Iselin, K. Koppensteiner, and G. Quasha, Barrytown, NY: Barrytown. Ltd., 1998, p. 15.

[2] R. Krauss, "Video: The aesthetics of narcissism," in Video Culture: A Critical Investigation, J.G. Hanhardt, Ed.pp. 180, 182.

[3] A locus classicus is Adorno's dialectical reading of Schoenberg and Stravinsky in Philosophy of New Music, Trans. A. G. Mitchell and W. V. Blomster. New York: Continuum, 2003. Adono's exemplary work on music can also be found in the following texts: Prisms, S. \& S. Weber, Trans. Cambridge, MA: MIT Press, 1983; Essays on Music, S. H. Gillespie, Trans. Berkeley and Los Angeles: University of California Press, 2002; Quasi una Fantasia: Essays on Modern Music, R. Livinstone, Trans. London and New York: Verso, 1998; and Beethoven: The Philosophy of Music, E. Jephcott, Trans. Palo Alto, CA: Stanford University Press, 1998. For M. Weber's sociological study of music, seeThe Rational and Social Foundations of Music, D. Martindale, J. Riedel, and G.Neuwirth, Trans. Carbondale, IL: Southern Illinois University Press, 1958. See also E. W. Said,On Late Style: Music and Literature against the Grain, New York: Vintage Books, 2006, as well as Said and D. Barenboim, Parallels and Paradoxes: Explorations in Music and Society, New York: Vintage, 2004.

[4] N. J. Paik, "Pensées' at 59," in Nam June Paik: Video Time - Video Space,T. Stooss and T. Kellein, Eds. New York: Harry N. Abrams, Inc., 1993, p. 17.

[5] For my own analysis of Schoenberg's twelve-tone composition as an abstract and depersonalizednarrative form, "Time Is Out of Joint": Totality, History, and Utopian Form in Adorno's Twelve-tone Philosophy," New Essays on the Frankfurt School of Critical Theory, A. J. Drake, Ed. London: Cambridge Scholars Publishing, 2009, pp. 141-167.

[6] For a theoretical account of twelve-tone composition, see A. Schoenberg, Fundamentals of Musical Composition. G. Strang and L Stein, Eds. London: Faber and Faber, 1970.In addition, Adorno'smagisterial critique of Schoenberg and later musicians is presented in "The Aging of the New Music," in Essays on Music, S. H. Gillespie, Trans. pp. 181-202; and "Versunemusiqueinformelle," in Quasi una Fantasia: Essays on Modern Music, R. Livingstone, Trans. pp. 269-322.

[7] M. Nyman, "Nam June Paik, composer," in Nam June Paik, J.G Hanhardt, Ed. New York: Whitney Museum of American Art, 1982, p 83.

[8] N. J. Paik, Nam June Paik: Videa 'n'Videology, Syracus, NY: Everson Museum of Art, 1974. p. 3

[9] N. J. Paik, “Afterlude,” Nam June Paik: Videa 'n'Videology, p. 11.

[10] G. Deleuze and F. Guattari, A Thousand Plateaus: Capitalism and Schizophrenia, University of Minnesota Press, 1987.

[11] H. K. Bhabha, The Location of Culture, London and New York: Routledge, 1994. p. 86.

[12] J. Cage, A Year from Monday, Middletown, CT: Wesleyan University Press, 1967, p. 90. 
[13] F. Jameson, Postmodernism, or, the Cultural Logic of Late Capitalism, Durham: Duke University Press, 1991, p. 76.

[14] S. Blumberg, Nam June Paik: Lessons from the Video Master, New York: IMP, 2007.

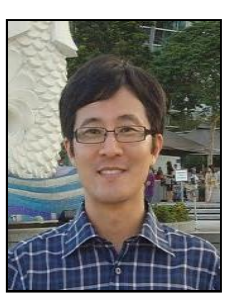

Koonyong Kim is an assistant professor in the Department of English at the University of San Diego. He earned his Ph.D. from Duke University, NC, USA in 2010. His research and teaching focuses on contemporary American literature, Asian American literature, critical theory, new media and cultural studies, architecture, musicology, and aesthetics.

He has published papers on postmodern global culture, new media, musicology, Hegel, poststructuralism, and the Frankfurt School. His current book project, tentatively entitled Across the Global Pacific: Mapping Contemporary Social Space and Transnational Cultural Forms, is a critical intervention into the emerging field of Transpacific Studies, and reconfigures US literature and culture from global and transnational perspectives. Bringing together a wide array of innovative forms from American, Asian American, and East Asian literatures and cultures, he illustrates the ways in which transnational cultural exchange within and across the Pacific has played a shaping role in the inception and evolution of new global cultural forms and media, including, most notably, cyberpunk, electronic and digital literature, the transnational urban narrative, video art, cinematographic writing, postmodern architecture, anime, and online computer gaming. 